\title{
Molecular identification and artificial cultivation of a wild isolate of oyster mushroom in Albania
}

\author{
Jordan Merkuri, ${ }^{1}$ Stefania Mirela Mang, ${ }^{2}$ Ippolito Camele, ${ }^{2}$ Magdalena Cara, ${ }^{1}$ \\ Gian Luigi Rana ${ }^{2}$ \\ ${ }^{1}$ Department of Plant Protection, Agricultural University of Tirana, Tirana, Albania; \\ 2School of Agricultural, Forestry, Food and Environmental Sciences, University of Basilicata, \\ Potenza, Italy
}

\begin{abstract}
Basidiomata of a wild mushroom macroscopically recognised as Pleurotus ostreatus were observed on an oak trunk in a mixed wood of northern Albania. Pure cultures of the fungus were then obtained on potato-dextrose-agar medium. Molecular analyses of genomic DNA of the fungus confirmed its identification. The rDNA ITS region nucleotide sequence of the studied Pleurotacea matched at $99 \%$ those of two P. ostreatus strains already present in NCBI GenBank database. The rDNA ITS nucelotide sequences of two pure cultures of the Albanian $P$. ostreatus were deposited in EMBL database under the accession numbers LN849458 and LN849459. One of the fungus isolates was subsequently cultivated under protected and semi-natural conditions. Productivity and biological efficiency of the Albanian $P$. ostreatus ranged from about $10 \%$ to $16 \%$ and from 33 to $53.33 \%$, respectively. This seems to be the first report on the artificial cultivation of $P$. ostreatus in Albania and could have, in the next future, a high economic impact on development and diffusion of this important edible mushroom over the country.
\end{abstract}

\footnotetext{
Correspondence: Ippolito Camele, School of Agricultural, Forestry, Food and Environmental Sciences, University of Basilicata, viale dell'Ateneo Lucano 10, 85100 Potenza, Italy.

E-mail: ippolito.camele@unibas.it
}

Key words: Cultivation, molecular analysis; polymerase chain reaction; Pleurotus ostreatus; substrate pasteurisation.

Funding: this work was supported by the Agency of Research Technology and Innovation in Albania.

Received for publication: 30 June 2015.

Revision received: 23 October 2015.

Accepted for publication: 24 October 2015.

(C) Copyright J. Merkuri et al., 2016

Licensee PAGEPress, Italy

Italian Journal of Agronomy 2016; 11:704

doi:10.4081/ija.2016.704

This article is distributed under the terms of the Creative Commons Attribution Noncommercial License (by-nc 4.0) which permits any noncommercial use, distribution, and reproduction in any medium, provided the original author(s) and source are credited.

\section{Introduction}

Although cultivation of Pleurotus ostreatus (Jacq.: Fr.) Kum., as reported by Delmas (1989), was initially attempted in Germany at beginning of last century using pieces or wheels of broadleaf wood as a growth substrate, its large spread on straw compost in the world occurred through ' 70 years of the last century thanks to the initial works of Vessey (1969) and Ferri (1972). Ferri et al. report, in 2007, China as the major producer of $P$. ostreatus basidiomata with about 2.3 ton milions and Italy, with about 30,000 tons as the first producer in Europe. Pileus of $P$. ostreatus, as well as that of Pleurotus eryngii (D.C.: Fr.) Quél., contains lovastatin, a statin drug used for lowering cholesterol ematic level and prevention of cardiovascular diseases (GundeCimerman, 1999; Wasser and Weis, 1999). Furthermore, the cellular wall of both Pleurotus species contains some particular carbohydrates which seem useful to trigger human defences against viral, bacterial and fungal diseases. Some basidiomata of a mushroom closely resembling P. ostreatus (Ferri, 1985; Ferri et al., 2007) were found growing on an oak trunk in a mixed wood of the Derven forest located near Rreshen town (Tirana province) in autumn 2009. Because no Pleurotus species was so far artificially and intensively cultivated in Albania, it seemed worthwhile, first of all to identify by molecular methods the mushroom and successively to attempt its artificial cultivation in the same country.

\section{Materials and methods}

\section{Mushroom isolation and storage}

Isolation of dikaryotic mycelium of the fungus was accomplished in axenic conditions at Plant Protection Laboratory belonging to the Department of Plant Protection, Faculty of Agriculture and Environment, Agricultural University of Tirana at the end of October 2009. potato-dextrose-agar added of $300-\mathrm{ppm} / \mathrm{L}$ streptomycin (PDA + s) was used as the first isolation medium. Small fungus flesh pieces, axenically picked-up from different wild basidiomata, specifically from the internal zone between stem and pileus, were singly placed into 10 $\mathrm{cm}$ diameter Petri dishes containing the above-mentioned medium. Pure cultures of the mushroom under study were obtained by successive transfers on PDA of periferal small portions of the fungal colonies grown on PDA + s (Cara et al., 2012).

Several pure culture replicates were kept in vials at $4^{\circ} \mathrm{C}$ on oatmeal-agar and then stored in the fungal collection of School of Agricultural, Forestry, Food and Environmental Sciences (University of Basilicata, Potenza, Italy). 


\section{DNA extraction, polymerase chain reaction amplifica- tion and molecular identification}

Genomic DNA (gDNA) was extracted from $400 \mathrm{mg}$ mycelium aliquots of ten single pure cultures with the commercial DNeasy Plant Mini DNA extraction kit (Qiagen, Hilden, Germany), following manufacturer's instructions. Concentration of the gDNA was determined using a ND-1000 spectrophotometer (NanoDrop Technologies Inc., Wilmington, DE, USA) and, then, adjusted to 50-100 ng/uL. DNA samples were stored at 20 and $80^{\circ} \mathrm{C}$ for short and long-term use, respectively.

The gDNA was amplified using the universal primer pair ITS4/TS5 (White et al., 1990). Sterile distilled water was used as a negative control. Polymerase chain reaction (PCR) was performed with an automated thermal cycler (Model 'One personal') of EuroClone S.p.A. (Pero, Milan, Italy) in a $50 \mu \mathrm{L}$ reaction volume containing $125 \mu \mathrm{M}$ of the four dNTPs, $0.5 \mu \mathrm{M}$ of each primer, $1 \mathrm{U}$ of DyNAzyme EXT DNA polymerase, $1 \mathrm{x}$ polymerase buffer, $4 \mu \mathrm{L}$ of template DNA (40-50 ng) and water. More specifically, amplification was carried out according to the following protocol: an initial heating at $94^{\circ} \mathrm{C}$ for $3 \mathrm{~min}$, followed by 35 cycles at $94^{\circ} \mathrm{C}$ for $30 \mathrm{~s}, 50^{\circ} \mathrm{C}$ for $30 \mathrm{~s}$ and $72^{\circ} \mathrm{C}$ for $1 \mathrm{~min}$ and a final extension at $72^{\circ} \mathrm{C}$ for $10 \mathrm{~min}$. After electrophoresis, carried out with a $1 \mathrm{~Kb}$ DNA Ladder (Invitrogen, Thermo Fischer Scientific, Rodano, Milan, Italy) in $1.2 \%$ agarose gel in TAE buffer (40 mM Tris-acetate, $1 \mathrm{mM}$ EDTA, pH 8), five $\mu \mathrm{L}$ of the amplified products were visualised under a UV transilluminator and stained with ethidium bromide $\left(0.5 \mu \mathrm{g} \mathrm{mL}^{-1}\right)$. Finally, amplicons were purified using a QIAquick Gel Extraction Kit (Qiagen) and directly sequenced by BMR Genomics (Padua, Italy). The resulting sequences were compared with those available in NCBI GenBank for $P$. ostreatus using the BLAST software (Altschul et al., 1997).

\section{Cultivation and productivity}

Preliminary artificial cultivation tests showed that all the pure cultures of Pleurotus species under study grew and produced in a satisfactory mode and without significant differences on a pasteurised standard substrate wetted at 70\% with water (w:w) and composed by 2-3cm-long pieces of wheat straw (50\%) and shattered corn stems and bracts (50\%) (Ferri et al., 2007). Therefore, only one of them was then employed in cultivation tests on the above substrate, added of $10 \%$ soy flour, $2.5 \%$ ammonium nitrate and $5 \% \mathrm{CaCO}_{3}$ powder and adjusted to an initial $\mathrm{pH}$ of 6.5. Substrate pasteurisation was performed at $70-72^{\circ} \mathrm{C}$ for $12 \mathrm{~h}$, after a pre-heating phase with hot water at $60^{\circ} \mathrm{C}$ for $2 \mathrm{~h}$ according to Muez-Orobia (1993). Substrate was then kept at $50-52^{\circ} \mathrm{C}$ for $36 \mathrm{~h}$ and gradually cooled to $25^{\circ} \mathrm{C}$ in the successive $12 \mathrm{~h}$. Sterile wheat kernels well invaded by mycelium of the selected strain were prepared as spawn at the Department of Plant Protection, Faculty of Agriculture and Environment, Agricultural University of Tirana. Inoculation was accomplished in axenic conditions thoroughly mixing $15-20 \mathrm{~g}$ of spawn to each $10 \mathrm{~kg}$ substrate portions which were then packed into single plastic bags furnished, on their surface, of 15 holes, each having $2 \mathrm{~cm}$ in diameter. Incubation phase lasted about 25 days and was performed at $28-30^{\circ} \mathrm{C}$ directly in cultivation greenhouses or tunnels shadowed at $75 \%$ with polyethylene black net. Four cultivation tests were performed: three under protected conditions and one in a woody habitat. More precisely, the first three were carried out with 200 substrate bags/each trial, in the agricultural farms Irakli Shkoza in Divjaka territory (Lushnja province), Mirela Muca (Tirana) and Ilir Beshi (Tirana) from October to December 2010 whereas the fourth was performed employing sixty substrate bags, in the farm of Xhevdet Mancaku (Ndroq district-Tirana) from February to March 2011 (Figure 1). In this last cultivation test, the substrate bags were transferred, after incubation, in a hidden woody location, characterised by abundance of Crataegus spp. as a shrub, were there hunged to branches of Quercus robur L. or Carpinus orientalis Mill. at 120-170 cm from soil surface and never sprayed with tap water because of the rainy season. Cultivation environments of the first three farms were vice versa equipped with automatic sprinklers that guaranteed repeated atomised water sprays during basidioma differentiation and growth phases.

Each cultivation cycle lasted about 60-65 days and 70-75 days under protected and semi-natural conditions, respectively. Visual inspections of the substrate bags put in cultivation were done each 2-3 days to verify the eventual occurrence of insect attacks and/or appearance of alterations caused by fungal or bacterial parasites. Basidiomata harvesting was operated, just before sporulation, at 15-20 days intervals, during each cultivation cycle, mainly three times in the first conditions and four times in the second. Successive, minor and economically not important sporophore harvests were not registered. Basidiomata were commonly picked up when their cap diameter at maximum measured $8-12 \mathrm{~cm}$.
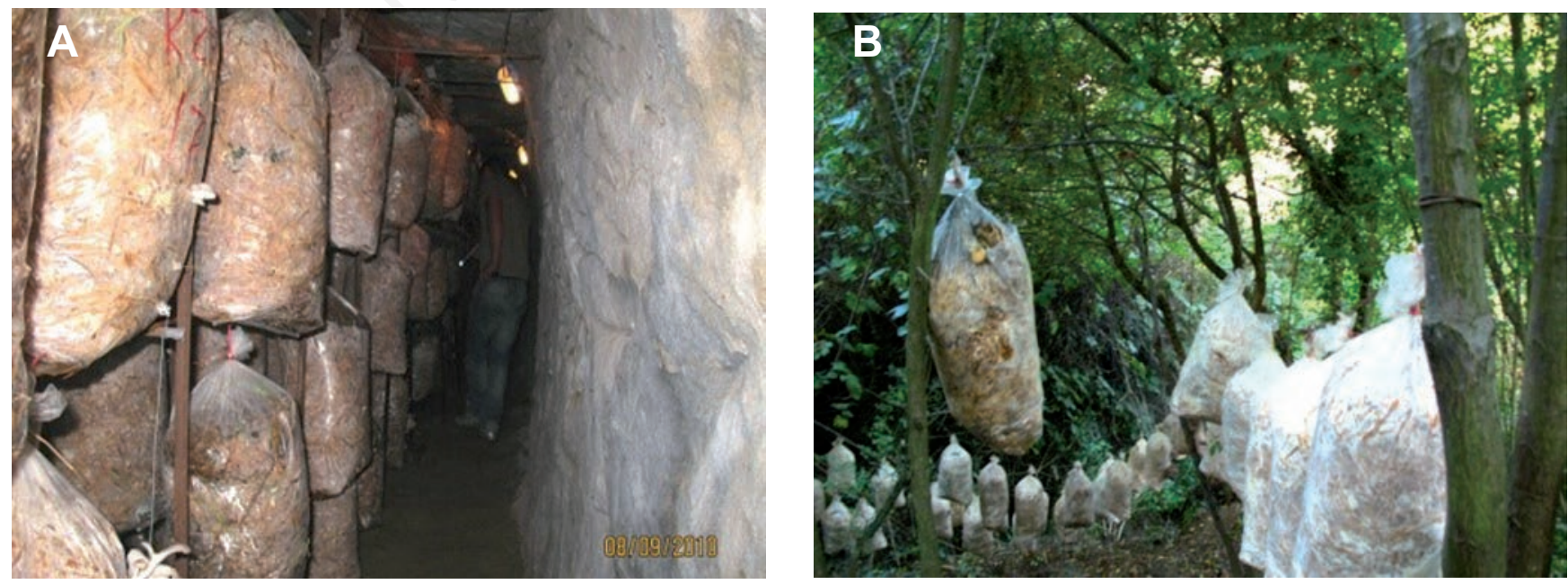

Figure 1. An internal view of a cultivation tunnel (A). Substrate bags hunged to branches of Carpinus orientalis in the Ndroq forest (B). 


\section{Yield and biological efficiency}

Fresh basidioma average weight (FBAW), expressed in grams, was calculated on a representative sample of 400 sporofores randomly collected among those altogether harvested during the four cultivation trials. Biological efficiency was calculated using the following formula (Chang et al., 1981):

$\mathrm{BE}=\mathrm{FWB} / \mathrm{DWC} \times 100$

where:

FWB = fresh weight of basidiomata; and

DWC $=$ dry weight of compost or substrate.

Productivity (P) expressed in percentage, was determined according to the following equation:

$\mathrm{P}=\mathrm{FWB} / \mathrm{FWS} \times 100$

where:

FWB = fresh weight of basidiomata; and

FWS $=$ fresh weight of substrate.

\section{Results}

\section{Morphology of the fungus}

Wild basidiomata of the Albanian isolates of Pleurotus perfectly matched morphological features of $P$. ostreatus well described in several mycological treatises and electronic resources (see at: www.indexfungorum.org) (Phillips, 1985; Papetti et al., 1999).

Isolation of the studied fungus was successful and fifteen pure cultures were obtained. Ten of them were selected for further investigations. Morphology of their colonies on PDA was identical to that of $P$. ostreatus described in details in a previous work on the same Albanian mushroom (Cara et al., 2012).

\section{DNA extraction, polymerase chain reaction amplifica- tion and molecular identification}

Genomic DNA extraction was successfully performed for all the selected pure cultures of the studied mushroom. The extracted gDNA concentration ranged from 250 to $350 \mathrm{ng} / \mu \mathrm{L}$. PCR, performed with the ITS4/ITS5 primer pair, produced visible amplicons around $600 \mathrm{bp}$ (Figure 2) for all samples tested. No amplification products were found in negative controls. Two oyster mushroom ITS nucleotide sequences obtained in this study were deposited into EMBL database archive under the accession numbers LN849458 and LN849459. Albanian rDNA ITS nucleotide sequences were very similar and closely related (similarity coefficient $=99 \%$ ) to those of the $P$. ostreatus strains S041 and S042 from China, present in NCBI GenBank with the accession numbers AY540324 and AY540325.

\section{Cultivation and productivity}

Pileus cuticle of the Albanian artificially produced $P$. ostreatus basidiomata had a light grey colour (Figure 3) and their flesh consistency was tender.

Performance of the Albanian isolate of $P$. ostreatus in cultivation tests was satisfactory. In fact, its $\mathrm{P}$ and $\mathrm{BE}$ ranged from 10 to $16 \%$ and from 33 to 53.33\%, respectively (Table 1). Each single substrate bag produced a minimum of $0.5 \mathrm{~kg}$ and a maximum of $3 \mathrm{~kg}$ of fresh basidiomata depending on the occurrence of massive or weak insect and/or Trichoderma spp. attacks, respectively. The best performance was shown in semi-natural conditions with an average FBW/substrate bag of $1.5-1.8 \mathrm{~kg}$. Finally, the FBAW ranged from 54.3 to $67.8 \mathrm{~g}$.

\section{Discussion}

The xylophilous mushroom, found in Mirdita forestry territory in Albania and identified as $P$. ostreatus on the basis of morphological and molecular analyses, was successfully cultivated for the first time in the same country.

The highest BE value, i.e., 53.33\%, was achieved in Mancaku farm. This very probably happened thanks to the almost complete absence of insect infestations, Spring season incoming and consequent prolonged basidiomata production in forestry conditions. In fact, in the above location, it was possible to operate four harvests in about 75 days with 12-day intervals.

Results here presented, if compared with those regarding the opti-

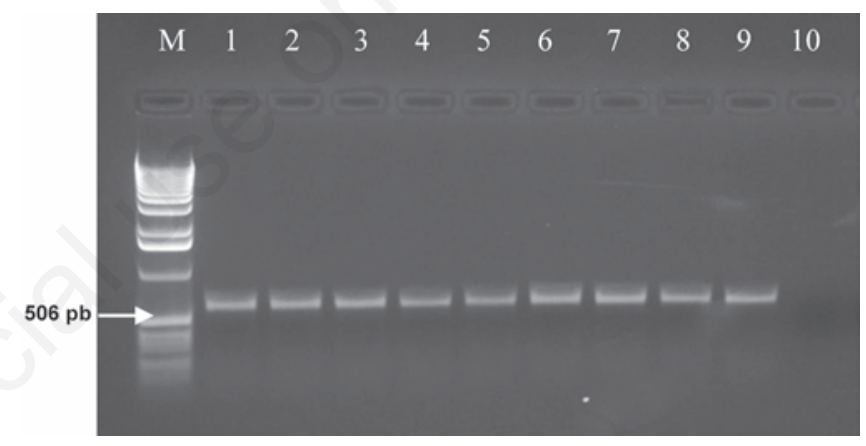

Figure 2. Result of gel electrophoresis of polymerase chain reaction amplification products obtained from Pleurotus ostreatus with ITS4/ITS5 primers set. Lane $M=1 \mathrm{~Kb}$ DNA ladder (Invitrogen); Lanes: 1-9 = ITS amplicons of 9 different Albanian P. ostreatus gDNA samples; 10 = negative control.

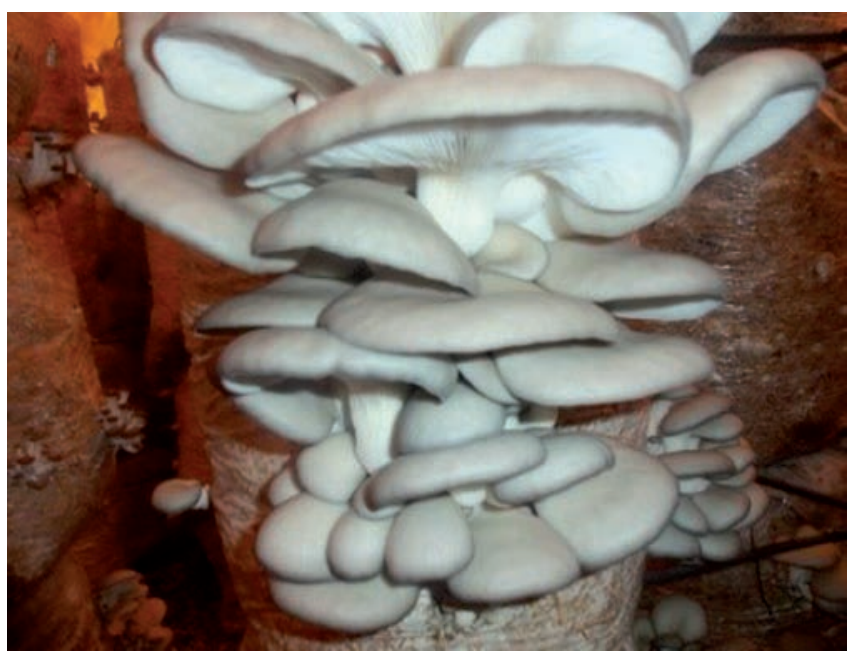

Figure 3. Close up of the gregarious basidiomata growth of the Albanian Pleurotus ostreatus. 
Table 1. Productivity and biological efficiency of the Albanian Pleurotus ostreatus in cultivation tests carried under protected and semi-natural (Xhevdet Mancaku) conditions.

\begin{tabular}{lccccc} 
Farm & $\begin{array}{l}\text { Dry substrate weight } \\
(\mathbf{q})\end{array}$ & $\begin{array}{c}\text { Wet substrate weight } \\
(\mathbf{q})\end{array}$ & $\begin{array}{c}\text { Total basidiomata fresh yield } \\
(\mathbf{q})\end{array}$ & $\begin{array}{c}\text { Productivity } \\
(\mathbf{q})\end{array}$ & $\begin{array}{c}\text { Biological efficiency } \\
(\%)\end{array}$ \\
Irakli Shkoza & 6.00 & 20.00 & 1.98 & 9.90 & 33.00 \\
Mirela Muca & 6.00 & 20.00 & 2.00 & 10.00 & 33.33 \\
\hline Ilir Beshi & 6.00 & 20.00 & 2.53 & 12.65 & 42.16 \\
Xhevdet Mancaku & 1.80 & 6.00 & 0.96 & 16.00 & 53.33 \\
\hline
\end{tabular}

mal Italian P values for the same Pleurotacea, i.e., 20-25\% (Ferri et al., 2007), are encouraging and along with the relatively low cost of the mushroom on market and its high versatility in kitchen, would suggest the opportunity of continuing these preliminary studies.

All future efforts should be planned to either investigate the natural presence in other Albanian areas of different $P$. ostreatus isolates eventually characterised by a more pleasant, intense taste and a higher basidiomata yield in artificial cultivation conditions or to improve the substrate composition.

Interesting could be also to extend these studies to search Albanian basidiomata of $P$. eryngii, mushroom commonly known as the king oyster mushroom, for producing them in some pioneer intensive cultivations with the goal to commercialise a Pleurotus species undoubtedly, for taste and flesh tenacity, known to be superior to the oyster mushroom even if Albanian $P$. ostreatus basidiomata artificially produced in this work, when cooked, resulted tender and tasteful.

Considering that the fresh pro capite mushroom consumption per year in Albania is very low (400-500 g) especially in comparison to Italy (about $1 \mathrm{~kg}$ ) and other countries (Germany, Belgium, United States of America) in which it reaches $2-2.5 \mathrm{~kg}$ and results of a preliminary market investigation (Merkuri and Cara, unpublished results), it seems advisable to promote a major production of fresh basidiomata of $P$. ostreatus and popularise knowledge regarding artificial cultivation of $P$. eryngii in Albania, in the next future.

It is matter of fact that the oyster mushroom so far encountered the consumer's and restaurator's favour in the country and request of its fresh basidiomata is high and remains mostly unsatisfied.

\section{References}

Altschul SF, Madden TL, Schaffer AA, Zhang J, Zhang Z, Miller W, Lipman DJ, 1997. Gapped BLAST and PSIBLAST: a new generation of protein database search programs. Nuc. Ac. Res. 25:3389-402.

Cara M, Merkuri J, Qesja B, Shkoza E, 2012. Nutrient Media estimation via "in vitro" cultivation of edible mushrooms Pleurotus spp. pp. 346-351 in Proc. Intern. Conf. "Towards future sustainable development”, Nov. 16-17, Shkodër, Albania. University of Shkodra, Luigj Gurakuqi, Shkodër, Albania.

Chang ST, Lau OW, Cho KY, 1981. The cultivation and nutritive value of Pleurotus sajor- caju. Eur. J. Appl. Microbiol. Biotechnol. 12:58-62.

Delmas J, 1989. Les champignons et leur culture. Flammarion ed., Paris, France.

Ferri F, 1972. Prove di coltivazione di alcuni isolamenti di Pleurotus ostreatus Quél. Micol. Ital. 1:11-8.

Ferri F, 1985. I funghi - micologia, isolamento, coltivazione. Edagricole, Bologna, Italy.

Ferri F, Zjalic S, Reverberi M, Fabbri AA, Fanelli C, 2007. I funghi. Coltivazione e proprietà medicinali. Edagricole, Bologna, Italy.

Gunde-Cimerman N, 1999. Medicinal value of the genus Pleurotus (Fr.) P. Karst. (Agaricales S.R., Basidiomycetes). Int. J. Med. Mushrooms 1:69-80.

Muez-Orobia MA, 1993. Bases para o cultivo de Pleurotus. pp 129-137 in Jornadas técnicas del champiñ n y otros hongos comestibles em Castilla-La Mancha, I, Anais Cuenca. Consejera de Agricultura y Medio Ambiente.

Papetti C, Consiglio G, Simonini G, 1999. Atlante fotografico dei funghi d'Italia. Vol. 1. AMB Ed., Trento, Italy.

Phillips R, 1985. Mushroom and other fungi of Great Britain and Europe. Istituto Geografico De Agostini Ed., Novara, Italy.

Vessey E, 1969. Culture industrielle des champignons sylvestres en Hongrie. Rev. Myc. 34:7-108.

Wasser SP, Weis AL, 1999. Medicinal properties of substances occurring in higher Basidiomycetes mushrooms: current perspectives (Review). Int. J. Med. Mushrooms 1:31-62.

White TJ, Bruns T, Lee S, Taylor JW, 1990. Amplification and direct sequencing of fungal ribosomal RNA genes for phylogenetics. In: M.A. Innis, D.H. Gelfand, J.J. Sninsky, T.J. White (Eds.), PCR protocols: a guide to methods and applications. Academic Press Ed., San Diego, CA, USA, pp 315-322. 